\title{
Information-seeking to support wellbeing: A pilot study of New Zealand men
}

\author{
Peta Wellstead · Hugh Norriss
}

\begin{abstract}
In New Zealand, compared to women men have poor health outcomes in a range of domains. Men also report barriers (both personal and structural) in seeking information to improve health and wellbeing. This paper reports a pilot project that investigated the informationseeking of New Zealand men during episodes of mental and physical ill health. The research investigated the ways in which information can be provided to encourage men to engage in information-seeking in a more timely way to improve their health and wellbeing. Results suggest that New Zealand men face considerable barriers accessing information and support and that the pathways to care are often unclear or absent. These findings demonstrate challenges and opportunities to service providers in terms of engaging men. Further research opportunities are also discussed.
\end{abstract}

Keywords: Wellbeing; Information-Seeking; Men

\section{Introduction}

Within both government and community services throughout the developed world considerable expertise exists for measuring health behaviors and social outcomes for the population and this work is undertaken routinely. A response to this social analysis is often the development of information products and services to inform the community as to how changes in behavior can lead to better personal, family, and community outcomes and increased wellbeing. These initiatives take a number of forms and include TV and newspaper advertisements, websites, telephone help lines, letter box distribution of printed materials or promotional products, community advertising and bill board displays. It is the central premise of this paper that the information needs of New Zealand men in the area of health and wellbeing are not well understood by service providers and that information provided to men oftentimes does not meet men's need. This leads to poor uptake of help and support by men who need it and to a waste of resources.

Information needs, seeking and use are responses to the world in which the subject finds himself or herself. There must be a perceived need for information to which there is a consequent response, either to seek out new information (approach motivation) or to ignore that need (avoidance motivation). Using need as a framework, it is therefore the case that using information and in turn increasing knowledge is a transitional process from a state of "distressing ignorance to becoming informed" (Buckland, 1988, p. 115).

While the rationale for increased information delivery seems valid, much of this activity takes little account of human information behavior, and particularly the way that different groups in society seek and use information. There is a presumption that all people seek and use information

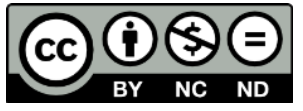

Copyright belongs to the author(s) www.internationaljournalofwellbeing.org 
in the same way and that this engagement leads to subsequent behavior change. "When considering the development of information products and services information researchers need to better understand the need for balance [in people's lives]. How do we balance information as a positive force in the lives of people against their desires to ignore it in order to continue to live in the relative calm and "normal" world that constitutes their small world of emotional safety and predictability?" (Chatman, 2000, p. 16).

A study of information-seeking, in this case an examination of information-seeking habits of New Zealand men, must set that behavior within the context of the life of the subject overall. The personal styles that individuals use to seek and use information have an enormous impact on the worth of the information that has been created. Some people are purposive foragers (Spink \& Cole, 2006, p. 25) in times of need, others are reactive to life's demands and take a more eclectic approach to finding information, while others have a more considered and cognitive style, so they collect and retain information which they think may have a value later. Other studies show that the social demography of the seeker may impact both information-seeking style and the way information is used (Case, 2007). It is clear also that there is a large group in society who are 'information avoiders'. A recent Australian study (Wellstead, 2010) found considerable avoidance in the information-seeking behavior of Australian men experiencing periods of life stress.

This information behavior research demonstrates that individuals function informationally in complex ways, both alone and in groups. These styles vary depending on the personality and temperament of the individual, the functioning of group behavior, and the interrelationship between those two elements. A large number of studies over many decades has shown that men are less likely than women to seek help when experiencing periods of poor wellbeing, and across the life-span more generally (Case, 2007; Connell, 1999; Mackenzie, Reynolds, Cairney, Streiner, \& Sareen, 2012; Mahalik, Good, \& Englar-Carlson, 2003; McMullen \& Gross, 1983; Mechanic, 1978; Palsdottir, 2005).

Despite a community-wide increase in service provision to support health and wellbeing and a corresponding attempt to increase mental health literacy across all age groups, the majority of people experiencing mental health problems, particularly men, do not seek help. Wellbeing is closely related to a range of mental health measures including life satisfaction and availability of help and support during periods of life stress and duress. Globally, more than $70 \%$ of people with mental illness receive no formal help or treatment (Henderson, Evans-Lacko, \& Thornicroft, 2013).

Research suggests that members of the community discount mental ill-health in men more often than they do in women (Swami, 2012; Wellstead, 2010) and that attempts to change community perception about mental health through community education campaigns have not been successful. The results of a recent Australian study indicate that despite intensive community education programs over the last two decades, there has been little change in those who are depressed and suicidal in terms of their attitudes toward seeking treatment and, more importantly, their treatment-seeking behavior (Chamberlain, Goldney, Taylor, \& Eckert, 2012). There is also evidence that men, when faced with periods of ill health, lack skills to source appropriate timely information and support to assist them into the care they need (Ek, 2013; Palsdottir, 2003; Wellstead, 2010).

A considerable element of feelings of wellbeing is the willingness to seek information and support. Social support, and particularly the information sharing embedded within it, has long been considered integral to health and wellbeing (Carveth \& Gottlieb, 1979; Eckenrode \& Gore, 1981; B R Sarason, Sarason, \& Pierce, 1990; Wellman \& Gulia, 1999). Friendship ties are a 
significant component in the complex behavior that is manifest in the giving and receiving of help, and it is clear that men and women use friends differently during periods of life stress and duress (King \& Terrance, 2006; Spencer \& Pahl, 2006; Wright, 1982; Wright \& Scanlon, 1991). It has also been established that it is not just the receiving of help that is supportive, but also there is a supportive element in knowing help is available even if one chooses not to use it (Antonucci \& Jackson, 1990; B. R Sarason, Pierce, \& Sarason, 1990; Short, 1996).

Delays in seeking information lead to consequent delays in accessing care and receiving appropriate intervention and support (Chatman, 1991b; Goldberg \& Huxley, 1980; Jorm et al., 2003; Oliver, Pearson, Coe, \& Gunnell, 2005). Those without information to support their everyday life needs, including their health information needs, can be considered "information poor". It has been suggested that the typical member of the community who is considered information poor "does not know which formal channels to tap into in order to solve his problems ... watches many hours of television daily... seldom reads... does not see his problems as information needs... is not an active information seeker... is locked into an informal information network that is deficient in the information that is ordinarily available to the rest of society" (Childers \& Post, 1975). While Childers and Post are using the masculine pronoun other studies have shown that women too are information poor in a range of contexts (Chatman, 1985, 1991a; Harris \& Dewdney, 1994; Lempert, 1992). Little work has been to done to explore links between help-seeking behavior and wellbeing. The purpose of this project is to address this gap. The study under review in this paper had three goals:

1) It investigated the information-seeking behavior of New Zealand men about matters of health and wellbeing;

2) It sought the views of participants about ways that the health and wellbeing of New Zealand men could be supported;

3) It sought the views of participants about ways New Zealand men might be encouraged to seek information and support more readily during periods when their wellbeing might be compromised.

\section{Context}

New Zealand is a country of almost 4.5 million people. New Zealand is a bicultural country; 67.6 percent of the people have European heritage, 14.6 percent belong to the Māori ethnic group. New Zealand is also a country of migrants; 22.9 percent of people in New Zealand were born overseas. For people born overseas who live in New Zealand, the most common birthplace is England (Statistics New Zealand, 2013). The laws, customs and social norms of New Zealand society as a whole are strongly based within English traditions and history, although reengagement with Maori traditions and culture has been an aspect of New Zealand civic life over the last 20 or so years.

The Health of New Zealand Adults 2011/12 survey (New Zealand Ministry of Health, 2012a) confirmed ongoing differences between men and women in health status, health behaviors and health service use. The survey reports that while men have poorer health than women in many areas they are less likely than women to have visited a GP, practice nurse or dental health care worker in the past year.

Of particular concern for the health and wellbeing of the New Zealand community is that, while New Zealand women have higher rates of diagnosed mental health conditions and reported psychological distress, New Zealand men commit suicide at very much higher rates. There were 380 male suicide deaths (17.0 deaths per 100,000 male population, age-standardized) in 2010. In the corresponding period there were 142 female suicide deaths (6.4 deaths per 100,000 
female population, age-standardized). The ratio of male to female suicide death rate was 2.7:1 in 2010. In the age range 15-24, the elevated rate of male suicide is even more obvious with 23.8 deaths per 100,000 population (New Zealand Ministry of Health, 2012b).

Another feature of New Zealand society is the rate of road trauma and its impact on community wellbeing. Despite substantial progress over the last 30 years, New Zealand still lags behind many other countries in road safety, and road trauma deaths are high. Over 250 deaths occur on New Zealand roads each year. Road crash death is highest in 14-44 year-olds and a significant proportion of these deaths occur in men. Alarmingly, in 2011, 12, 574 New Zealanders were killed or injured in road accidents: two-thirds of these were men, and many women killed or injured were in motor vehicles driven by men (New Zealand Ministry of Transport, 2012).

In February 2011 the Canterbury region, including New Zealand's second largest city, Christchurch, experienced a devastating earthquake that left 181 dead, many injured and homeless, and the entire country in a state of shock and upheaval. A significant part of the population of Christchurch had to be rehoused in the Christchurch region and many relocated elsewhere while the city center is rebuilt and social services are restored. There has also been ongoing community anxiety about the response of the insurance industry to consumer distress about the claims process. This work is ongoing and will take many years. The media have reported the Christchurch earthquake and its aftermath in a style that has heightened community concerns and increased the "fear factor" in the community at large. Ongoing aftershocks in the Christchurch region and new quakes (albeit smaller) in other parts of the country have contributed to this anxiety. The research under review in this paper was conducted against this backdrop.

\section{Method}

Data were collected from men in the New Zealand community by means of an online questionnaire using the survey tool SurveyMonkey. The line of questioning reflected the instrument designed by the lead author as part of her doctoral research. This research examined the information-seeking behavior of Australian men during periods of life stress and duress. Given the close historical and social ties between Australia and New Zealand it was considered that the original survey instrument was a valid platform to examine the information-seeking behavior of New Zealand men. In consultation with the Mental Health Foundation of New Zealand and other industry partners the instrument was refined to reflect more closely the lives of New Zealand men, with particular reference to the lives of Maori and Pacific Islander men.

The survey was launched to coincide with the Movember campaign. During November each year, the Movember campaign in New Zealand and around the world encourages men to seek sponsorship to grow a moustache, the aim of which is to raise vital funds and awareness for men's health, specifically prostate cancer and men's mental health (Movember Foundation, 2013).

The questions in the survey were divided into four major categories: demographic data, availability of social support, information-seeking behavior and open-ended questions soliciting information about strategies that could be adopted to improve the health and wellbeing of New Zealand men.

The survey was promoted by the Mental Health Foundation of New Zealand (MHF) with a link to the questionnaire on the MHF website. Industry partners were made aware of the survey and it was widely promoted through industry networks using email broadcasts, list-servs, promotional material and by advertorial in newsletters. 
The survey was available online between November 1, 2012 and January 3, 2013. Men from all sections of the New Zealand community were invited to take part. Five incentive prizes from a major hardware chain were offered to men who took part if they consented to include their email details at the conclusion of the survey.

\section{Results}

\subsection{Demography}

Three hundred and seven New Zealand men entered the survey; 282 completed it (a completion rate of $91.1 \%$ ). Most participants had Anglo Saxon heritage $(78.4 \%)$ and were between the ages of $45-64(55 \%)$. Most of the participants (84.1\%) were wage and salary earners. Half of the participants $(50.9 \%)$ had university qualifications, either at graduate or postgraduate level. Most participants $(71 \%)$ had an income above $\$ 50,000$ per annum. Overwhelmingly the men in this study were married $(61.8 \%)$ or had a partner with whom they lived $(17.1 \%)$. Of the men with children, $36.1 \%$ were the parent of an adult over the age of 25 . A further $30.4 \%$ had young adult children aged between 18 and 25. More than a quarter (26.4\%) were the parent of 6-12 year olds. Of the men with children, $50.6 \%$ recorded that their children lived with them.

\subsection{Alcohol consumption}

Drinking alcohol is a significant component of social life New Zealand society. To a question regarding the consumption of alcohol 300 men responded (7 did not complete this question). $8.3 \%$ reported that they never drink alcohol and $30 \%$ reported that they only drink occasionally. $5.3 \%$ reported that they drink alcohol every day.

\subsection{Spirituality}

Spirituality is a feature of the lives of many of the participants with over $60 \%$ answering "yes" or "somewhat" to the question "Do you think of yourself as a spiritual person, for example believing in a higher power, God, or the supernatural?" These inclinations are obviously matters of private concern as, significantly, $75 \%$ of participants did not identify themselves as belonging to, or taking part in, any formal religious or cultural group, e.g. church or Marae.

\subsection{General health}

The vast majority of the men (85\%) reported that their health was good to excellent on a 6-point scale (excellent to poor).

\subsection{Life satisfaction}

A significant number of participants (18\%) indicated that they were either dissatisfied or very dissatisfied with their lives on a 6-point scale from very satisfied to don't know. $71 \%$ were satisfied or very satisfied.

\subsection{Social support}

Over $60 \%$ of the men indicated that they felt isolated at some point during the month prior to taking the survey on a 6-point scale (never to always).

Notwithstanding these feelings of isolation for a large group who completed the survey, $91 \%$ of respondents indicated that there were people in their network from whom they could seek help and support, and with whom they could discuss private matters. These people were family members, friends and colleagues. Of particular note is that 45 participants (15\%) skipped the 
question that asked them to identify people in their network that they could call on for help. This is considerably more than the $9 \%$ who indicated in the previous question that they had no one to call on for help and support.

Over half of participants (54\%) indicated that they socialized monthly or less often with people outside their family. While sociability outside the family was reported thus, $62 \%$ of participants indicated that they are part of a club, sporting team or community organization and $60 \%$ of those who answered this question indicated that they take part in activities with these groups fortnightly or more often. These findings appear to be contradictory.

Participants were asked to indicate how many people within their social network they felt they could call on for help and support. Overwhelmingly most of the men (72\%) indicated that they have 1-2, or 3-5 confidants, with some men indicating that there is no one they can call on. Again some men (17) did not answer the question.

Ninety-six percent of participants indicated that they are someone who provides help and support to others, both those inside their families and elsewhere. Significantly, many participants indicated that they provide help and support to work colleagues, employees and clients, that is, people outside their family and friendship network.

\subsection{Information seeking and use}

In answer to the question "Who was most helpful to you when you needed information and support?", significantly, only 186 participants responded (121 did not). The responses fell into six major categories: Friends, Family members, People at work, Professional Support, Spouse/partner and, reflecting the responses to the earlier question about spirituality, $9 \%$ of the men suggested their Spiritual Advisor was a significant source of information and support.

In terms of help and support that was available, many men indicated that they found the pathway to help difficult and perceived it to be unnecessarily complex. One man summed this up eloquently: somewhere to get answers without needing me to repeat myself (participant 47). And another: It's hard to know where to go when I want a good whinge! (participant 227)

Other men indicated that women seem to get more help and support during periods of illhealth: information on men's health and on issues for men is still relatively spartan compared with that available for women and children. There have been programmes for women's health in place for many decades. The same cannot be said for men (participant 45). Other men felt a level of resentment about the strong female presence in the services providing help and support: Every support avenue I could find was female as the default (initial victim support person, follow up on phone from victim support, counselor etc) - with no real emphasis on male needs (participant 171).

The willingness to seek help was also a factor for many men: The information is always available just depends if one is open enough to hear it at the time. From my observation humans want a quick fix so they don't have to put any effort in (participant 201). And: The biggest issue men have is admitting there's a problem and seeking help (participant 60).

Many men indicated that there was a need for men to support other men and to undertake shared activities that were just about "being together".

\subsection{Strategies for change}

This theme of "being together" and men supporting men was also a strong theme in the section that asked participants what might be done to improve the health and wellbeing of New Zealand men. Many men wrote moving stories about their struggles to find a clear path to being a man in the current era. It is clear that while this group of men were high achievers in terms of income and many hold positions of relative power in society, they feel somewhat lost as to how to 
function effectively in what they perceive to be a "feminized world" where masculinity, and its demands, are not well understood. These struggles were palpable in much of the writing: Men bond by doing stuff together. Women change the dynamic of how men can relate. There needs to be spaces where men can be men and interact how men do without women always attempting to participate or emulate. Women have enough groups to do their thing. There is also a time and place for men and women to be together. With men's groups I am a part of then we have invited women to join us for a limited period where it is not imposed on the men (participant 300).

There was also a sense of bewilderment in many of the responses. Don't know was a common response and only 156 (of the 307 participants) attempted to answer the question. Of those that did, a one-stop shop approach to service provision, men helping themselves, trust that information and support are credible and the need to know what is "normal" were common responses. And there was an undercurrent of quiet despair in many of the responses, summed up by Participant 236: Harden up, deal with it or die.

\section{Discussion}

What is apparent from this study is that when the men were experiencing a major stressful life event many of them were unfamiliar with likely sources of information and help. The men were also unclear about appropriate pathways they could use in order to gain assistance. The pathways were either blurred or in many cases concealed by their own lack of knowledge of resources or help that might be available. They were also reluctant to seek out what they knew to be available due to their perceptions of what was normal behavior for men. These notions of "normal" created considerable gender role strain (Pleck, 1995) for them and created additional stress.

While many men expressed concern that they could not find the information and support they needed, others used a variety of strategies at different times to obtain the help they needed. These results are consistent with other studies (e.g. A. R. Berger \& Janoff-Bulman, 2006; M. Berger, Wagner, \& Baker, 2005; Finn \& Bishop, 2006; Gottlieb, 1981; Stokes \& Wilson, 1984) that show that help is mobilized in a variety of ways depending on the contextual circumstances of the help that is required. Not all available help is mobilized in the same way, or indeed, mobilized at all.

The helping value of those within a social network is measured not only by those who provided help but also by those who were not called on. This decision not to call on certain people (who can be identified as potential helpers) is complex and not well understood (Antonucci \& Jackson, 1990; Nadler \& Mayseless, 1983; Short, 1996; Trivers, 1971).

Another major source of anxiety was the likelihood that their concerns would not be taken seriously because information and support services are set up to meet the needs of women. The role of women as confidants and sources of information for men in this study is also apparent. Even for those men without a partner, women were important confidants: mothers, sisters and female friends were all indicated as confidants. This finding is consistent with other studies. In an examination of the impact of gender role orientations and friendship Wright and Scanlon (1991) cite a variety of studies which show that "men tend to be more open, more self-disclosing, and more intimate with their women friends than their men friends" (p. 552).

Most of the men in the study indicated that there are three to five people to whom they feel close. Initially the small size of the social network of the men in the current study seemed inconsistent with the literature from other studies. A Californian study of 1050 people in 1977 showed that numbers in the average social network were close to 10 (Fischer \& Phillips, 1982). The $19^{\text {th }}$ British Social Attitudes survey (Park \& Roberts, 2002), which surveyed 3,500 randomly 
selected respondents, found that $56 \%$ of men have 10 or more close friends (although $17 \%$ said they have no best friend at all). In another study reported in the Sunday Times (UK) (Dobson \& Iredale, 2005) it was suggested "it takes a network of 18 close friends and relatives to provide an average person with the emotional and practical support to get through day-to-day life" (p. 11).

While these numbers are higher than for the men in the current study, it is important to consider what those in these networks mean to the people who have identified them. Spencer and Pahl (2006, p. 45), in discussing their research into personal networks in the UK, make the point that it is important when considering such studies to consider, "those who are important to them [the participants] at the time, rather than all the people they know no matter how tenuous the connection". Spencer and Pahl draw on the work of others to indicate that personal communities typically consist of 3-6 socially close intimate ties, 5-15 less strong but still significant ties, and approximately 1000 acquaintances and latent (but often still mobilizable) relationships (Wellman \& Gulia, 1999).

A great deal of research has examined this dilemma of reciprocity in the giving and receiving of help (e.g., Antonucci \& Jackson, 1990; A. R. Berger \& Janoff-Bulman, 2006; Fisher, Nadler, \& Whitcher-Alagna, 1983; Reinhardt, Boerner, \& Howowitz, 2006) and the burden that receiving help may imply. An Australian study (Short, 1996) has shown social class has a large bearing on the willingness of people to engage in informal economic exchange, with higher class people less likely to do so. For the purposes of Short's study, informal economic exchange means economy as social support rather than purely monetary exchange.

This concept is best understood as the need to find information and help from those whom one believes will provide the type of support which best matches the event at hand due to the fact "the particular components of social support that impact on health and illness vary dependent upon the types of stresses being confronted by the person" (Cutrona \& Russell, 1987, p. 62). Similarly it can be suggested that "event sequence, operant illness beliefs, structural conditions and human agency interpenetrate the occurrence and timing of pivotal actions and denouncement of a help-seeking episode" (Uchara, 2001, p. 519).

Taking account of these studies of social network density and the numbers considered optimum to ensure social connectedness and personal wellbeing, the fact that most men in this study have indicated they only have 3-5 close relationships might indicate that they are suffering some level of social and emotional isolation. But by including the word "close" in this study it might indicate that these men have similar patterns of relating to those identified above by Wellman \& Gulia (1999). That is, personal communities that typically consist of from 3 to 6 socially close intimate ties and of 5 to 15 less strong but still significant ties, but with much larger numbers in a wider network that can be called upon for specific types of support.

Notwithstanding the possible interpretation of the data in this study, what is clear is that the challenge in terms of wellbeing is to ensure that individuals not only have a strong social network but also one that includes a diversity of ties (Spencer \& Pahl, 2006) in order for the aforementioned optimum matching to occur in times of stress. It is worth noting that epidemiological research (Cohen, Doyle, Skoner, Rabin, \& Gwaltney, 1997) has found an increased relative risk of mortality among those with less diverse networks.

A large number of theoretical frameworks and graphical models seek to explain the complex phenomena of how people seek and use information. There have been writers who have suggested that there may be within individuals an "information disposition" (Childers, 1982, p. 104); others have suggested an evolutionary imperative (Spink, 2010); there are those that suggest that when seeking information humans are "gap-bridging" (Savolainen, 2000, pp. 43-45) and others suggest that "all information processing is emotional" (Dodge, 1991, p. 59). What is clear 
from these differing perspectives is that the process of information seeking is complex and not well understood, especially when it occurs during periods of stress or duress.

What is also clear is that some individuals and groups in society face particular barriers when faced with the demands of information-seeking and information use. Increasing information uptake within these hard-to-reach groups is a particular challenge for service providers. Many men in this study indicated that they are information poor in terms of resources to assist them with matters of health and wellbeing. Those who fall into the category of "information poor" are often considered as outsiders, that is, people living in a small world of limited resources (Chatman, 1991b, 1996) but the men in this study are, largely, not outsiders. They are welleducated individuals with above-average income from an Anglo Saxon background. Men such as these occupy positions of power in New Zealand society (as they do in many other countries) so are not outsiders or living in a "small world", yet in terms of information behavior about matters of wellbeing, they are information poor.

Sixty percent of the men who took part in this study identified themselves as experiencing feelings of social isolation. This is despite the fact that most of these men have high status within New Zealand society in terms of education and income, and that the vast majority of them are married or in a committed "marriage-like" relationship. This issue of social isolation and what the men are reporting is one of considerable complexity and needs further investigation.

\section{Limitations}

Notwithstanding wide publicity and that stakeholders in the Maori and Pacific Islander community were engaged with the survey, only 17 Maori men (6\%) took part in the survey. The participants were predominantly of New Zealand Anglo Saxon background. They were also mostly middle-aged, well-educated salaried professionals with above-average incomes. This sample bias is a major limitation of the study and the reason this paper is descriptive rather than analytical. Further work is needed during future research projects to engage with a wider cohort of New Zealand men in terms of their information-seeking to support wellbeing.

\section{Conclusion and recommendations}

This pilot study has identified some significant issues that would benefit from further investigation in terms of information-seeking by New Zealand men in regard to their health and wellbeing. These include:

- the role of men's social networks in providing information and brokering support in New Zealand, and the type of information and support embedded within these networks;

- the fact that many of the men perceive themselves as socially isolated, either some or all of the time, notwithstanding that most of the participants had a partner, employment and social status;

- the concept of information poverty within a group with seemingly good access to community resources due to their status, and

- the impact of changing gender roles within society as a contributor to men's health and wellbeing.

The last of these may contribute to anxiety among some sectors in the community, but given the poor health of New Zealand men and continuing high rates of suicide, road trauma, alcohol abuse and perceptions of social isolation, it is imperative to have this community conversation in order to design health policy initiatives that best meet men's need. Public health policy and the fiscal investment to provide it is designed to empower action leading to improved health 
outcomes. If these improved health outcomes are not forthcoming (and clearly with regard to the statistics relating to men's poor health and wellbeing they are not), then a serious analysis of gaps and inequities needs to occur.

Agencies and professionals offering information and help might also wish to consider in more detail the notion of "optimum matching" in the help-seeking experience, and how services can take account of this concept more readily when seeking to support men.

This pilot study has demonstrated that further research is required to better understand the way that New Zealand men seek information and support to enhance their wellbeing. More data are also required about the type of information and support that best meets men's needs in this domain in order that men have clear pathways to care when they need it. There is also considerable scope for further research of cross-cultural considerations of social network strength and provision of information and support. If the health and wellbeing of New Zealand is to be improved, more research is required to better understand men's information-seeking behavior and ways community agencies can develop information products and congruent services that men will find appealing and useful.

\section{Authors}

Peta Wellstead

Freelance Information Services

peta@freelanceinformationservice.com

Hugh Norriss

Mental Health Foundation of New Zealand

Hugh@mentalhealth.org.nz

\section{Publishing Timeline}

Received 22 July 2014

Accepted 12 August 2014

Published 31 December 2014

\section{References}

Antonucci, T. C., \& Jackson, J. S. (1990). The role of reciprocity in social connectedness. In B. R. Sarason, I. G. Sarason \& G. R. Pierce (Eds.), Social connectedness: an interactional view (pp. 205-226). New York: Wiley-Interscience.

Berger, A. R., \& Janoff-Bulman, R. (2006). Costs and satisfactions in close relationships: the role of lossgain framing. Personal Relationships, 13, 53-68. http://dx.doi.org/10.1111/j.1475-6811.2006.00104.x

Berger, M., Wagner, T. H., \& Baker, L. C. (2005). Internet use and stigmatized illness. Social Science and Medicine, 61, 1821 - 1827. http://dx.doi.org/10.1016/j.socscimed.2005.03.025

Buckland, M. K. (1988). Becoming informed. Library services in theory and context (pp. 115-129). Oxford: Pergamon Press.

Carveth, W. B., \& Gottlieb, B. H. (1979). The measurement of social support and its relation to stress. Canadian Journal of Behavioural Science, 11(3), 180-187. http://dx.doi.org/10.1037/h0081588

Case, D. O. (2007). Looking for information: a survey of research on information seeking, needs and behaviour (2nd ed.). London: Academic Press.

Chamberlain, P. N., Goldney, R. D., Taylor, A. W., \& Eckert, K. A. (2012). Have mental health education programs influenced the mental health literacy of those with major depression and suicidal ideation? A comparison between 1998 and 2008 in South Australia. Suicide \& Life-Threatening Behavior, 42(5), 525-540. http://dx.doi.org/10.1111/j.1943-278X.2012.00109.x 
Chatman, E. A. (1985). Information, mass media use and the working poor. Library E Information Science Research, 7, 97-113.

Chatman, E. A. (1991a). Channels to a larger social world: older women staying in contact with the great society. Library E Information Science Research, 13, 281-300.

Chatman, E. A. (1991b). Life in a small world: applicability of gratification theory to information-seeking behavior. Journal of the American Society for Information Science, 42(6), 438-499.

Chatman, E. A. (1996). The impoverished life-world of outsiders. Journal of the American Society for Information Science, 47(3), 193 - 206.

Chatman, E. A. (2000). Framing social life in theory and research. In L. Hoglund \& T. D. Wilson (Eds.), New review of information behaviour research: studies of information seeking in context (pp. 3-17). Cambridge: Taylor Graham.

Childers, T. (1982). Personal maintenance and personal growth. In G. P. Sweeney (Ed.), Information and the transformation of society (pp. 102-111). Amsterdam: North Holland Publishing Company.

Childers, T., \& Post, J. (1975). The information poor in America. Metuchen, N.J.: Scarecrow.

Cohen, S., Doyle, W. J., Skoner, D. P., Rabin, B. S., \& Gwaltney, J. M. (1997). Social ties and susceptibility to the common cold. Journal of the American Medical Association, 277, 1940-1944. http://dx.doi.org/10.1001/jama.1997.03540480040036

Connell, R. W. (Ed.). (1999). Men's health: a research agenda and background report. Canberra: Department of Health and Aged Care, Australia.

Cutrona, C. E., \& Russell, D. W. (1987). The provisions of social relationships and adaption to stress. Advances in Personal Relationships, 1, 37-67.

Dobson, R., \& Iredale, W. (2005, October 5). We all get by with a little help from our friends. The Sunday Times, p. 11.

Dodge, K. A. (1991). Emotion and social information processing. In J. Garber \& K. A. Dodge (Eds.), The development of emotion regulation and dysregulation (pp. 159-181). Cambridge: Cambridge University Press. http://dx.doi.org/10.1017/CBO9780511663963.009

Eckenrode, J., \& Gore, S. (1981). Stressful events and social supports: the significance of context. In B. H. Gotllieb (Ed.), Stressful events and social supports (pp. 43-68). Beverley Hills: Sage.

Ek, S. (2013). Gender differences in health information behaviour: a Finnish population-based survey. Health Promotion International (September 2013). http://dx.doi.org/10.1093/heapro/dat063

Finn, L., \& Bishop, B. (2006). Mutual help: an important gateway to wellbeing and mental health. http://www.connectgroups.org.au/resources/LizzieFinn.pdf

Fischer, C. S., \& Phillips, S. L. (1982). Who is alone? Social characteristics of people with small networks. In L. A. Peplau \& D. Perlman (Eds.), Loneliness; A sourcebook of current theory, research and therapy (pp. 21-39). New York: Wiley-Interscience.

Fisher, J. D., Nadler, A., \& Whitcher-Alagna, S. (1983). Four conceptualizations of reaction to aid New directions in helping (Vol. 1, pp. 51 - 85) New York: Academic Press Ltd.

Goldberg, D. P., \& Huxley, P. (1980). Mental illness in the community: the pathways to psychiatric care. London: Tavistock.

Gottlieb, B. H. (1981). Social networks and social connectedness. Michigan: Sage Publications.

Harris, R. M., \& Dewdney, P. (1994). Barriers to information: how formal help systems fail battered women. Westport, CT: Greenwood Press.

Henderson, C., Evans-Lacko, S., \& Thornicroft, G. (2013). Mental illness stigma, help seeking and public health programs. American Journal of Public Health, 103(5), 777-780. http://dx.doi.org/10.2105/AJPH.2012.301056

Jorm, A., Griffiths, K. M., Christensen, H., Korten, A. E., Parslow, R. A., \& Rodgers, B. (2003). Providing information about the effectiveness of treatment options to depressed people in the community: a randomised controlled trial of effects on mental health literacy, help-seeking and symptoms.

Psychological Medicine, 33, 1071-1079. http://dx.doi.org/10.1017/S0033291703008079

King, A. R., \& Terrance, C. (2006). Relationships between personality disorder attributes and friendship qualities among college students. Journal of Social and Personal Relationships, 2(1), 5-20.

http://dx.doi.org/10.1177/0265407506058696 
Lempert, L. (1992). The crucible: violence, helpseeking and abused women's transformation of self. (Doctoral Thesis) University of California, San Francisco.

Mackenzie, C. S., Reynolds, K., Cairney, J., Streiner, D. L., \& Sareen, J. (2012). Disorder-specific mental health service use for mood and anxiety disorders: associations with age, sex and psychiatric comorbidity. Depression and Anxiety, 29, 234-242. http://dx.doi.org/10.1002/da.20911

Mahalik, J. R., Good, G. E., \& Englar-Carlson, M. (2003). Masculinity scripts, presenting concerns, and help seeking: implications for practice and training. Professional Psychology: Research and Practice, 34(2), 123-131. http://dx.doi.org/10.1037/0735-7028.34.2.123

McMullen, P. A., \& Gross, A. E. (1983). Sex differences, sex roles, and health-related help-seeking. In D. M. DePaulo, A. Nadler \& J. D. Fisher (Eds.), New Directions in Helping - Volume 2 - Help-Seeking (Vol. 2, pp. 233-263). New York: Academic Press.

Mechanic, D. (1978). Sex, illness behaviour, and the use of health services. Social Science and Medicine, 12, 207-214.

Movember Foundation. (2013) About Movember. http://nz.movember.com/about

Nadler, A., \& Mayseless, O. (1983). Recipient self-esteem and reactions to help. In J. D. Fisher, A. Nadler \& B. M. DePaulo (Eds.), New Directions in Helping: Volume 1 - Recipient Reactions to Aid (Vol. 1, pp. 167-188). New York: Academic Press.

New Zealand Ministry of Health. (2012a). The Health of New Zealand Adults 2011/12: Key findings of the New Zealand Health Survey. Wellington: Ministry of Health. http://www.health.govt.nz/publication/health-new-zealand-adults-2011-12

New Zealand Ministry of Health. (2012b). Suicide facts: deaths and intentional self-harm hospitalisations 2010. http://www.health.govt.nz/publication/suicide-facts-deaths-and-intentional-self-harmhospitalisations-2010

New Zealand Ministry of Transport. (2012). Motor vehicle crashes in New Zealand 2011 http://www.transport.govt.nz/research/Documents/Motor-Vehicle-Crashes-in-New-Zealand2011.pdf

Oliver, M. I., Pearson, N., Coe, N., \& Gunnell, D. (2005). Help-seeking behaviour in men and women with common mental health problems: cross-sectional study. British Journal of Psychiatry, 186, $297-$ 301. http://dx.doi.org/10.1192/bjp.186.4.297

Palsdottir, A. (2003). Icelandic citizens' everyday life health information behaviour. Health Informatics Journal, 9(4), 225-240. http://dx.doi.org/10.1177/1460458203094001

Palsdottir, A. (2005). Health and lifestyle: Icelanders' everyday life information behaviour. (PhD Thesis), Abo Akademi Finland, Abo (Turku).

Park, A., \& Roberts, C. (2002). The ties that bind. In A. Park, J. Curtice, L. Thomson, L. Jarvis \& C. Bromley (Eds.), British social attitudes: the 19th report (pp. 185-211). London: Sage Publications. http://dx.doi.org/10.4135/9781849208659.n9

Pleck, J. H. (1995). The gender role strain paradigm: an update. In R. F. Levant \& W. S. Pollack (Eds.), A new psychology of men (pp. 11-32). New York: Basic Books.

Reinhardt, J. P., Boerner, K., \& Howowitz, A. (2006). Good to have but not to use: differential impact of perceived support and received support on well-being. Journal of Social and Personal Relationships, 23(1), 117-129. http://dx.doi.org/10.1177/0265407506060182

Sarason, B. R., Pierce, G. R., \& Sarason, I. G. (1990). Social connectedness: the sense of acceptance and the role of relationships. In B. R. Sarason, I. G. Sarason \& G. R. Pierce (Eds.), Social connectedness: an interactional view (pp. 97-121). New York: Wiley-Interscience.

Sarason, B. R., Sarason, I. G., \& Pierce, G. R. (Eds.). (1990). Social support: an interactional view. New York: John Wiley \& Sons.

Savolainen, R. (2000). Incorporating small parts and gap bridging: two methodological approaches to information use. In L. Hoglund \& T. D. Wilson (Eds.), New review of information behaviour reseach: information seeking in context (pp. 35-67). Cambridge: Taylor Graham.

Short, P. (1996). Kinship reciprocity and vulnerability: social relations in the informal economy. Australian Journal of Social Issues, 31(2), 126-145. 
Spencer, L., \& Pahl, R. (2006). Rethinking friendship: hidden solidarities today. Princeton/Oxford: Princeton University Press.

Spink, A. (2010). Information behavior: an evolutionary instinct. Berlin: Springer-Verlag. http://dx.doi.org/10.1007/978-3-642-11497-7

Spink, A., \& Cole, C. (2006). Human information behaviour: integrating diverse approaches and information use. Journal of the American Society for Information Science and Technology, 57(1), 25-35. http://dx.doi.org/10.1002/asi.20249

Statistics New Zealand. (2013). Census Data 2006. http://www.stats.govt.nz/Census/2006CensusHomePage/QuickStats/AboutAPlace.aspx

Stokes, J. P., \& Wilson, D. G. (1984). The inventory of socially supportive behaviours: dimensionality, prediction, and gender differences. American Journal of Community Psychology, 12(1), 53-69. http://dx.doi.org/10.1007/BF00896928

Swami, V. (2012). Mental health literacy of depression: gender differences and attitudinal antecedents in a representative British sample. PLoS ONE 7(11). http://dx.doi.org/10.1371/journal.pone.0049779

Trivers, R. L. (1971). The evolution of reciprocal altruism. Quarterly Review of Biology, 46, 35-57. http://dx.doi.org/10.1086/406755

Uchara, E. S. (2001). Understanding the dynamics of illness and help-seeking: event-structure analysis and a Cambodian-American narrative of spirit invasion. Social Science and Medicine, 52, 519-536. http://dx.doi.org/10.1016/S0277-9536(00)00157-X

Wellman, B., \& Gulia, M. (1999). The network basis of social support: a network is more than the sum of its ties. In B. Wellman (Ed.), Networks in the global village: life in contemporary communities (pp. 83-118). Oxford: Westview Press.

Wellstead, P. (2010). Information behaviour of Australian men experiencing stressful life events: the role of social networks and confidants. Information Research, 16(2), paper 474.

Wright, P. H. (1982). Men's friendships, women's friendships and the alleged inferiority of the other. Sex Roles, 8(1), 1-20. http://dx.doi.org/10.1007/BF00287670

Wright, P. H., \& Scanlon, M. B. (1991). Gender role orientations and friendship: some attenuation, but gender differences abound. Sex Roles, 24(9/10), 551-566. http://dx.doi.org/10.1007/BF00288413 